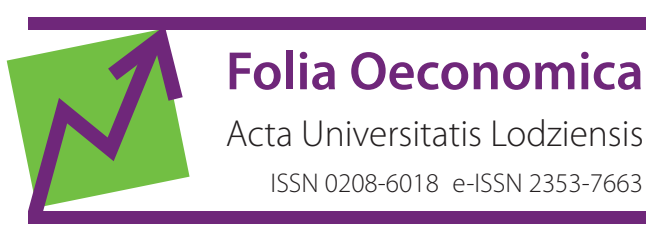

www.czasopisma.uni.lodz.pl/foe/

4(330) 2017

DOI: http://dx.doi.org/10.18778/0208-6018.330.06

\title{
Artur Zaborski
}

Wroclaw University of Economics, Faculty of Economics, Management and Tourism in Jelenia Góra, Chair of Econometrics and Computer Science, artur.zaborski@ue.wroc.pl

\section{The Influence of Triad Selection on the Preference Scaling Results}

\begin{abstract}
In the method of triads for a set of $n$ objects all three element sets of objects are presented to the respondents. A respondent is asked to pick out the most similar and the least similar pair. The method of triads, despite its numerous advantages, is rarely used in practice. The number of triads is a cubic function of the number of objects and increases very rapidly with the number of objects. The aim of the study is to indicate the possibility of scaling preferences based on the reduced number of triads. It has also been examined whether the change of reduced set of triads influences the results of the scaling. The results of the analysis are illustrated by an empirical example in which preference scaling for different sets of triads was performed with the use of TRISOSCAL program.
\end{abstract}

Keywords: measurement of preferences triads, preference scaling, TRISOSCAL

JEL: C38, C63, M31 


\section{Introduction}

The measurement of preferences can be conducted on the basis of historical observations of consumer behaviour, or on the basis of data describing consumer intentions. In the second case, the measurement of preferences is performed using methods which express consumer attitudes at the time of research. One such method is the method of triads, in which respondents express their opinions about the preferences for all possible groups of three objects, taken from the full set of $n$ objects. This method is very laborious, especially when a large number of objects is tested.

The aim of the article is to indicate the possibility of scaling preferences based on the reduced number of triads. It was examined whether the reduction of the number of triads and the change of the set of triads affect the final scaling results. The use of the method was illustrated by an empirical example, in which the calculation and presentation of the results were carried out using the TRISOSCAL program available in the NewMDSX package.

\section{The preferences collecting methods}

A necessary decision to be taken at the initial stage of the preference research is the choice of the method of collecting information about subjects' preferences. So far, many methods of collecting preference data have been developed and applied (see. e.g. Bijmolt, 1996: 30-31; Zaborski, 2001: 40-43). Some of them suggested in the literature are presented in Table 1.

The preference collecting methods differ considerably as far as the task to be performed by the subjects is concerned. Differences between the methods pertain to three factors:

1) the number of objects simultaneously presented to respondents - in contrast with, for example, paired comparisons and triads, methods like conditional ranking and sorting give a subject the opportunity to inspect the entire set of objects when $\mathrm{s} /$ he makes her/his judgements;

2) the difficulty of each preference evaluation to be made - e.g. the simultaneous comparison of numerous objects to a single reference object in the method of conditional ranking or arrangement of all possible pairs of objects in order of decreasing similarity in the ranking of pairs is more complicated than comparing only one pair of objects as in the method of paired comparisons;

3) the total number of preference evaluations to be made - e.g. in sorting and in ranking the task is essentially a single preference evaluation, whereas comparison dyads or triads yield a task of numerous evaluations.

These factors jointly determine the effects of the data collection methods on various aspects of the preference research process. The choice of method af- 
fects the subjective feelings of the respondents, i.e. fatigue, boredom, or difficulties in expressing preference evaluations (see Figure 1). As a result, the collected data may be incomplete or not always fully reflect the respondents' attitudes.

Table 1. The preference collection methods

\begin{tabular}{|l|l|}
\hline \multicolumn{1}{|c|}{ Method } & \multicolumn{1}{c|}{ Description } \\
\hline Sorting & $\begin{array}{l}\text { The subject has to sort the objects into a number of groups, with relative- } \\
\text { ly similar objects in each group }\end{array}$ \\
\hline Paired comparisons & $\begin{array}{l}\text { For all pairs of objects the subject has to indicate the most preferred } \\
\text { object }\end{array}$ \\
\hline Ratings & $\begin{array}{l}\text { The subject has to rate each pair of objects on an ordinal scale, where the } \\
\text { extreme values of the scale represent maximum dissimilarity and maxi- } \\
\text { mum similarity }\end{array}$ \\
\hline Ranking & The subject has to arrange the objects from the most to the least preferred \\
\hline Ranking of pairs & $\begin{array}{l}\text { The subject is requested to arrange all possible pairs of objects in order } \\
\text { of decreasing similarity }\end{array}$ \\
\hline Pick $k$ out of $n$ & $\begin{array}{l}\text { The subject is asked to pick a number of objects which s/he considers } \\
\text { most similar to a particular reference object. This process has to be done } \\
\text { several times while rotating the reference object }\end{array}$ \\
\hline Conditional ranking & $\begin{array}{l}\text { One object is presented to the subject as a reference object, and the re- } \\
\text { maining objects have to be ordered on the basis of their preference sim- } \\
\text { ilarity with the reference object. Each of the objects is in turn presented } \\
\text { as the reference }\end{array}$ \\
\hline Dyads & $\begin{array}{l}\text { For each pair of pairs of objects (dyad) the subject has to select the more } \\
\text { similar pair of the two }\end{array}$ \\
\hline Triads & $\begin{array}{l}\text { The subject has to indicate which objects of combinations of tree objects } \\
\text { form the most similar pair, and which form the least similar pair }\end{array}$ \\
\hline
\end{tabular}

Source: own elaboration

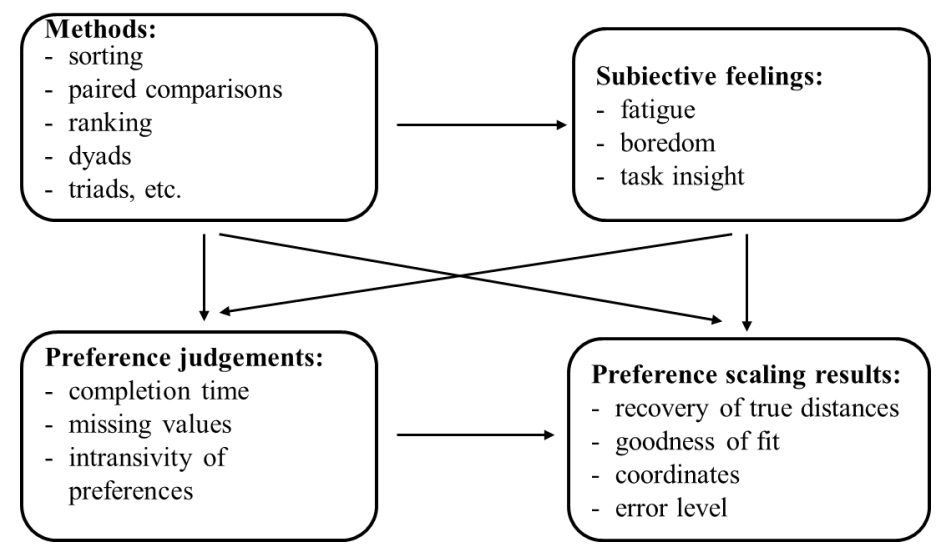

Figure 1. The impact of different data collecting methods on the preferences scaling results Source: own elaboration based on Bijmolt, 1996: 30-49 


\section{The method of triads}

In the method of triads the subject is asked to consider all possible groups of tree objects $\left(O_{i}, O_{j}, O_{k}\right)(i, j, k=1,2, \ldots, n$, where $i \neq j \neq k$ at a time, taken from the full set of $n$ objects $O=\left(O_{1}, O_{2}, \ldots, O_{n}\right)$. The subject has to indicate which two objects of each combination form the most similar pair, and which two objects form the least similar pairl. On this basis the triad is formed, where the most similar objects are placed as the first and the second, and the least similar as the first and the third one. For example, if $\left(O_{i}, O_{j}\right)$ is the most similar pair and $\left(O_{j}, O_{k}\right)$ is the least similar pair, the triad is $\left(O_{i}, O_{j}, O_{k}\right)$.

As each triad involves three paired comparisons, it is possible to enter the judgement on each of these paired comparisons into a matrix. The rows and columns of the matrix correspond to the pairs of objects. The element in the $i$-th row and the $j$-th column is 1 when the pair in the $i$-th row is judged to be more similar then the pair in the $j$-th column, and 0 otherwise. After summing the values of the elements of each row, the ordinal similarity preference scale of pairs of objects is obtained. The objects of a pair which received the highest number of points are treated as the most similar. Table 2 presents the described matrix for 5 objects marked with the consecutive letters of the alphabet and the 10 following triads assigned to them: $(B, A, C),(A, B, D),(B, A, E),(A, D, C),(C, E, A),(A, E, D),(B, D, C)$, $(\mathrm{E}, \mathrm{B}, \mathrm{C}),(\mathrm{B}, \mathrm{D}, \mathrm{E}),(\mathrm{D}, \mathrm{E}, \mathrm{C})$.

Table 2. The ordinal similarity preferences matrix

\begin{tabular}{|c|c|c|c|c|c|c|c|c|c|c|c|}
\hline & $\mathbf{A B}$ & $\mathbf{A C}$ & $\mathbf{A D}$ & $\mathbf{A E}$ & $\mathbf{B C}$ & $\mathbf{B D}$ & $\mathbf{B E}$ & $\mathbf{C D}$ & $\mathbf{C E}$ & $\mathbf{D E}$ & Sum \\
\hline $\mathrm{AB}$ & 0 & 1 & 1 & 1 & 1 & 1 & 1 & 0 & 0 & 0 & 6 \\
\hline $\mathrm{AC}$ & 0 & 0 & 0 & 0 & 1 & 0 & 0 & 0 & 0 & 0 & 1 \\
\hline $\mathrm{AD}$ & 0 & 1 & 0 & 0 & 0 & 0 & 0 & 1 & 0 & 0 & 2 \\
\hline $\mathrm{AE}$ & 0 & 1 & 1 & 0 & 0 & 0 & 1 & 0 & 0 & 1 & 4 \\
\hline $\mathrm{BC}$ & 0 & 0 & 0 & 0 & 0 & 0 & 0 & 0 & 1 & 0 & 1 \\
\hline $\mathrm{BD}$ & 0 & 0 & 1 & 0 & 1 & 0 & 1 & 1 & 0 & 1 & 5 \\
\hline $\mathrm{BE}$ & 0 & 0 & 0 & 0 & 1 & 0 & 0 & 0 & 1 & 0 & 2 \\
\hline $\mathrm{CD}$ & 0 & 1 & 0 & 0 & 1 & 0 & 0 & 0 & 0 & 0 & 2 \\
\hline $\mathrm{CE}$ & 0 & 1 & 0 & 1 & 0 & 0 & 0 & 1 & 0 & 0 & 3 \\
\hline $\mathrm{DE}$ & 0 & 0 & 1 & 0 & 0 & 0 & 1 & 1 & 1 & 0 & 4 \\
\hline
\end{tabular}

Source: own elaboration

The elements of the last column in Table 2 form triangular similarity matrix (see Table 3) on the basis of which preference scaling is carried out.

\footnotetext{
${ }^{1}$ It is also possible to use this method while indicating only the most similar par.
} 
The creation of the triangular preference similarity matrix is also possible by giving a pair of objects from the first and the second place in the triad two points, from the second and the third place one point, and from the first and the third place zero points. The value of an element in the $i$-th row and the $j$-th column of the matrix is the number of points awarded to a pair consisting of the $i$-th and the $j$-th objects in all triads.

Table 3. The similarity matrix

\begin{tabular}{|c|c|c|c|c|c|}
\hline & A & B & C & D & E \\
\hline A & - & & & & \\
\hline B & 6 & - & & & \\
\hline C & 1 & 1 & - & & \\
\hline D & 2 & 5 & 2 & - & \\
\hline E & 4 & 2 & 3 & 4 & - \\
\hline
\end{tabular}

Source: own elaboration

An advantage of the triads method is a relative simplicity of the judgments required of the subjects. Although it is a useful technique for data collection, the number of triads increases very rapidly with the number of objects. The number of triads is a cubic function of the number of objects and amounts to:

$$
\mathrm{C}_{n}^{k}=\frac{n(n-1)(n-2)}{6} \text {. }
$$

Each pair appears in triads $n-2$ times, while each object occurs $\frac{(n-1)(n-2)}{2}$ times. For 8 objects there are 56 triads, but for 14 objects there are 364 triads involving 1092 paired comparisons. Obviously, beyond about $n=8$, the presentation of the full set of triads becomes totally unfeasible and very laborious for the subject.

When the number of triads is considered too large to be practical, it can be reduced in such a way that all pairs of objects in triads are presented equally frequently, but less than $n-2$ times (see Roskam, 1970; Burton, Nerlove, 1976). If $\lambda$ denotes the number of triads in which each pair of objects occurs $(\lambda=1,2, \ldots$, $n-2)$ than the reduced number of triads is obtained by multiplying (1) by $\frac{\lambda}{n-2}$,
and is equal to:

$$
L_{\lambda}=C_{n}^{k} \cdot \frac{\lambda}{n-2}=\frac{\lambda n(n-1)}{6} .
$$


The number of triads for different values of $\lambda$ and $n$ are shown in Table 4 .

Table 4. The number of triads for different values of $\lambda$ and $n$

\begin{tabular}{|c|c|c|c|c|c|c|c|c|}
\hline \multirow{2}{*}{$\boldsymbol{n}$} & \multicolumn{9}{|c|}{$\boldsymbol{\lambda}$} & \multicolumn{2}{|c|}{$\begin{array}{c}\text { Full set } \\
\text { of triads }\end{array}$} \\
\cline { 2 - 9 } & $\mathbf{1}$ & $\mathbf{2}$ & $\mathbf{3}$ & $\mathbf{4}$ & $\mathbf{5}$ & $\mathbf{6}$ & $\mathbf{7}$ & $\times$ \\
\hline 6 & 5 & 10 & 15 & 20 & $\times$ & $\times$ & $\times$ & 20 \\
\hline 7 & 7 & 14 & 21 & 28 & 35 & $\times$ & $\times$ & 35 \\
\hline 8 & - & - & 28 & - & - & 56 & $\times$ & 56 \\
\hline 9 & 12 & 24 & 36 & 48 & 60 & 72 & 84 & 84 \\
\hline 10 & 15 & 30 & 45 & 60 & 75 & 90 & 105 & 120 \\
\hline 11 & - & - & 55 & - & - & 110 & - & 165 \\
\hline 12 & 22 & 44 & 66 & 88 & 110 & 132 & 154 & 220 \\
\hline 13 & 26 & 52 & 78 & 104 & 130 & 156 & 182 & 286 \\
\hline 14 & - & - & 91 & - & - & 182 & - & 364 \\
\hline 15 & 35 & 70 & 105 & 140 & 175 & 210 & 245 & 455 \\
\hline 16 & 40 & 80 & 120 & 160 & 200 & 240 & 280 & 560 \\
\hline
\end{tabular}

Source: own elaboration

Because it is not possible to define a reduced number of triads for all combinations of $\lambda$ and $n$, not all the cells in Table 4 are filled.

\section{The assessment of the impact of triads choice on preferences scaling}

In order to make scaling results independent from respondents' subjective effects (fatigue, boredom, task insight), the reliability of the use of a reduced number of triads was made on the basis of the given distance matrix (see Table 5). The matrix shows the dissimilarities in the preferences of the University of the Third Age members in relation to the selected forms of activities (see Zaborski, 2014). For the data in Table 5 a full set of 84 triads was determined. Than the preference scaling was performed with the use of TRISOSCAL (TRIadic Similarities SCALing) program, which provides an internal analysis of a set of triadic (dis)similarity measures by a Minkowski distance model (see: Coxon, 1982: 155-158).

The quality of matching the resulting points configuration to the configuration determined based on the distance matrix (Table 5) was tested by a Procrustes statistic:

In the next stage, six sets of triads were generated, one for each $\lambda$ value (see Table 6 ). Figure 3 presents the results of the scaling for each set of triads and fitting measures of obtained configuration to the configuration determined for the full set of triads. 
Table 5. The preferences dissimilarity matrix

\begin{tabular}{|l|l|c|c|c|c|c|c|c|c|c|}
\hline \multicolumn{2}{|c|}{ Activities } & $\mathbf{1}$ & $\mathbf{2}$ & $\mathbf{3}$ & $\mathbf{4}$ & $\mathbf{5}$ & $\mathbf{6}$ & $\mathbf{7}$ & $\mathbf{8}$ & $\mathbf{9}$ \\
\hline 1 & English & 0.000 & & & & & & & & \\
\hline 2 & German & 0.694 & 0.000 & & & & & & & \\
\hline 3 & Computer skills & 1.372 & 1.128 & 0.000 & & & & & & \\
\hline 4 & Gymnastics & 0.908 & 1.111 & 0.766 & 0.000 & & & & & \\
\hline 5 & Yoga & 0.596 & 1.007 & 1.062 & 0.370 & 0.000 & & & & \\
\hline 6 & Swimming & 1.117 & 1.276 & 0.712 & 0.209 & 0.568 & 0.000 & & & \\
\hline 7 & Weight training & 1.395 & 1.413 & 0.530 & 0.522 & 0.892 & 0.342 & 0.000 & & \\
\hline 8 & Nordic walking & 0.754 & 1.291 & 1.333 & 0.578 & 0.318 & 0.723 & 1.065 & 0.000 & \\
\hline 9 & Painting and handcraft & 1.196 & 0.663 & 0.637 & 1.071 & 1.190 & 1.138 & 1.104 & 1.507 & 0.000 \\
\hline
\end{tabular}

Source: own elaboration

$$
R^{2}=\frac{\left\{\operatorname{tr}\left(\mathbf{X}^{T} \mathbf{Y} \mathbf{Y}^{T} \mathbf{X}\right)^{\frac{1}{2}}\right\}^{2}}{\operatorname{tr}\left(\mathbf{X}^{T} \mathbf{X}\right) \operatorname{tr}\left(\mathbf{Y}^{T} \mathbf{Y}\right)}
$$

where $\mathrm{X}$ - configuration of points determined on the basis of the triads, and $\mathrm{Y}$ - configuration of points determined on the basis of the distance matrix. $R^{2} \in(0 ; 1)$, where 1 means a perfect matching. $R^{2}$, for configuration determined based on triads, reached 0.9813 , which indicates a very good fitting of both configurations.

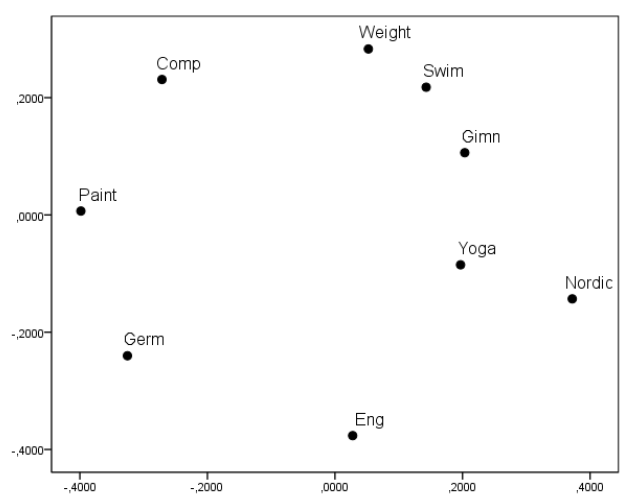

Figure 2. Preference map received based on the full triads set Source: own elaboration, using TRISOSCAL program 
Table 6. Triad sets for different $\lambda$

\begin{tabular}{|c|c|c|c|c|c|c|c|c|c|c|c|c|}
\hline$\lambda$ & \multicolumn{12}{|c|}{ Triads } \\
\hline$\lambda=1$ & $1,2,3$ & $6,4,5$ & $8,7,9$ & $7,4,1$ & $9,2,5$ & $3,6,8$ & $1,6,9$ & $8,4,2$ & $3,5,7$ & $8,5,1$ & $7,6,2$ & $3,9,4$ \\
\hline \multirow{2}{*}{$\lambda=2$} & $1,5,9$ & $3,2,8$ & $4,6,7$ & $2,9,6$ & $3,4,1$ & $8,5,7$ & $7,3,9$ & $4,5,2$ & $6,8,1$ & $8,4,9$ & $5,6,3$ & $2,1,7$ \\
\hline & $1,2,3$ & $6,4,5$ & $8,7,9$ & $7,4,1$ & $9,2,5$ & $3,6,8$ & $1,6,9$ & $8,4,2$ & $3,7,5$ & $8,5,1$ & $7,6,2$ & $3,9,4$ \\
\hline \multirow{3}{*}{$\lambda=3$} & $2,1,4$ & $2,5,3$ & $4,6,3$ & $5,4,7$ & $8,5,6$ & $6,7,9$ & $1,8,7$ & $9,2,8$ & $3,9,1$ & $3,4,1$ & $4,5,2$ & $5,6,3$ \\
\hline & $4,6,7$ & $8,5,7$ & $8,6,9$ & $7,9,1$ & $2,1,8$ & $3,9,2$ & $2,1,6$ & $7,3,2$ & $8,4,3$ & $5,4,9$ & $6,5,1$ & $7,6,2$ \\
\hline & $3,7,8$ & $8,4,9$ & $1,5,9$ & $1,6,3$ & $7,4,2$ & $8,5,3$ & $6,4,9$ & $1,5,7$ & $8,6,2$ & $7,3,9$ & $4,8,1$ & $9,2,5$ \\
\hline$\lambda=4$ & \multicolumn{12}{|c|}{ complement of triads set for $\lambda=3$} \\
\hline$\lambda=5$ & \multicolumn{12}{|c|}{ complement of triads set for $\lambda=2$} \\
\hline$\lambda=6$ & \multicolumn{12}{|c|}{ complement of triads set for $\lambda=1$} \\
\hline
\end{tabular}

Source: own elaboration
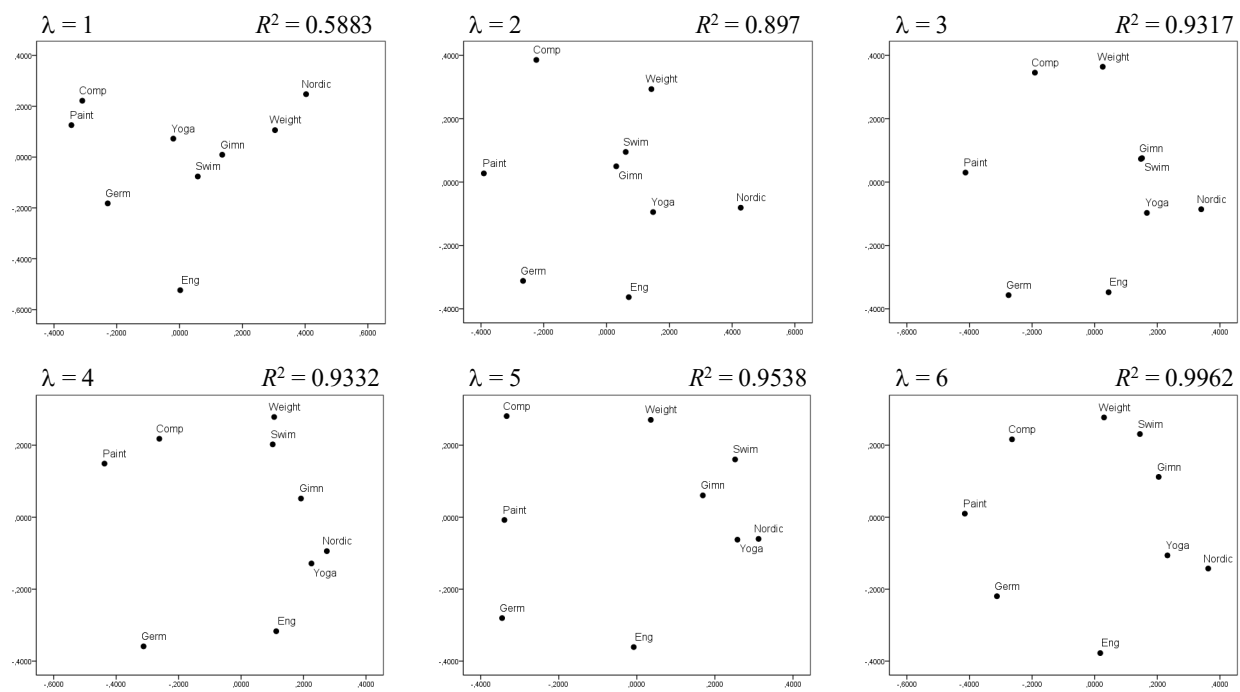

Figure 3. Preference maps for different value of I

Source: own elaboration, using TRISOSCAL program

There are many sets of triads which may be generated for each value of $\lambda$. To verify how the choice of a triads set affects the preference scaling results, 18 sets of triads were generated, 3 for each value of $\lambda$. As it was mentioned previously, it is not possible to determine a reduced number of triads for all combinations of $\lambda$ and $n$, and in consequence, all pairs of objects in triads cannot be presented equally frequently, each set was modified by adding randomly selected two triads and subtracting randomly selected two triads. Finally 54 sets of triads were obtained, 9 for each value of $\lambda$. For each set the preference scaling with the use of TRISOSCAL program was performed. The quality of matching of the resulting configura- 
tions of points to the configuration determined based on the full set of triads tested by a Procrustes statistic is presented in Table 7.

Table 7. Procrustes statistics for preference maps

\begin{tabular}{|c|c|c|c|c|c|c|}
\hline & $\lambda=\mathbf{1}$ & $\boldsymbol{\lambda}=\mathbf{2}$ & $\boldsymbol{\lambda}=\mathbf{3}$ & $\boldsymbol{\lambda}=\mathbf{4}$ & $\boldsymbol{\lambda}=\mathbf{5}$ & $\boldsymbol{\lambda}=\mathbf{6}$ \\
\hline$T_{1}$ & 0.58833 & 0.89727 & 0.93317 & 0.93176 & 0.95384 & 0.99630 \\
\hline$T_{1+}$ & 0.72367 & 0.91586 & 0.92873 & 0.93750 & 0.97521 & 0.99837 \\
\hline$T_{1-}$ & 0.66314 & 0.92851 & 0.92884 & 0.92990 & 0.96877 & 0.99530 \\
\hline$T_{2}$ & 0.66793 & 0.92180 & 0.92504 & 0.94970 & 0.94074 & 0.99246 \\
\hline$T_{2+}$ & 0.76821 & 0.91980 & 0.92494 & 0.94880 & 0.94064 & 0.99356 \\
\hline$T_{2-}$ & 0.48187 & 0.92476 & 0.93523 & 0.95422 & 0.94904 & 0.99116 \\
\hline$T_{3}$ & 0.44199 & 0.92305 & 0.94839 & 0.92497 & 0.93647 & 0.99528 \\
\hline$T_{3+}$ & 0.76605 & 0.92579 & 0.96405 & 0.91276 & 0.93494 & 0.99789 \\
\hline$T_{3-}$ & 0.59784 & 0.93758 & 0.96392 & 0.92545 & 0.93551 & 0.99304 \\
\hline$\overline{\mathrm{T}}_{i}$ & 0.63323 & 0.92160 & 0.93915 & 0.93501 & 0.94835 & 0.99481 \\
\hline $\mathrm{SD}$ & 0.11666 & 0.01096 & 0.01575 & 0.01371 & 0.01488 & 0.00246 \\
\hline
\end{tabular}

Explanations: $T_{i}$ - number of triad set, $T_{i+}$ - triad set after adding two triads, $T_{i-}-$ triad set after subtracting two triads, $\overline{\mathrm{T}}_{i}-$ mean, SD - standard deviation.

Source: own elaboration.

It can be seen that starting from the $\lambda=2$ results indicate a good matching in relation to the scaling carried out for the complete set of triads, whereas for $\lambda=6$ it should be regarded as almost perfect. There is only a small difference in the obtained results between $\lambda=2$ and $\lambda=5$ (the difference between the best and the worst solution for all sets of triads in this interval is less than 0.08 ). The low value of the standard deviation for all $\lambda$ (excluding the results for $\lambda=1$ ) attests to the fact that the choice of a set of triads has no significant effect on the results of preference scaling, even when all pairs of objects in triads cannot be presented equally frequently. The analysis shows that, excluding the results for $\lambda=1$ and $\lambda=6$, preference scaling after subtracting two triads generally gave a better fit than scaling performed based on the increased number of triads.

\section{Conclusions}

In view of the fact that the results of preference scaling on the basis of different collecting methods are similar (see e.g. Humphreys, 1982; Bijmolt, 1996: 33-34; Zaborski, 2003), the choice of the method of measurement should be guided pri- 
marily by two criteria: the method should not be labour-intensive, and expressing opinions on preferences should not cause problems to respondents. The full triad method does not satisfy the first of the above conditions. The number of ratings which a respondent must make for $n$ objects is equal to the number of three element combinations of $n$-element set. The article indicates the possibility of reducing the number of triads in such a way that each pair of objects appears in all triads equally frequently, but fewer than $n-2$ times. In the example for 9 objects it was shown that scaling preferences based on 36 triads (and even for 24 triads) gave a similar result as for the full set of 84 triads. It was also demonstrated that the choice of the incomplete set of triads has no significant effect on the results of preference scaling, even when all pairs of objects in triads cannot be presented equally frequently. This conclusion is particularly relevant for the creation of a reduced set of triads when the number of objects does not allow to fulfil the condition of an equal number of pairs.

The analysis shows the need to avoid collecting preference data by using triads where each pair appears in a set only once. This approach may be acceptable only if we use the opinion of many respondents, provided that a different set of triads is presented to each respondent.

\section{References}

Bijmolt T.H.A. (1996), Multidimensional Scaling in Marketing: Towards Integrating Data Collection and Analysis, Labyrint Publication, Capelle a/d Ussel.

Burton M.L., Nerlove S.B. (1976), Balanced design for triads tests: two examples from English, "Social Science Research", no. 5, pp. 247-267.

Coxon A.P.M. (1982), The User's Guide to Multidimensional Scaling, Heinemann Educational Books, Exeter.

Humphreys M.A. (1982), Data collecting effects on nonmetric multidimensional scaling solutions, "Educational and Psychological Measurement", no. 42, pp. 1005-1022.

Roskam E.E. (1970), The methods of triads for multidimensional scaling, "Nederlands Tijdschrift Voor de Psychologie", no. 25, pp. 404-417.

Zaborski A. (2001), Skalowanie wielowymiarowe w badaniach marketingowych, Wydawnictwo Akademii Ekonomicznej we Wrocławiu, Wrocław.

Zaborski A. (2003), Wpływ alternatywnych metod pomiaru preferencji na wyniki skalowania wielowymiarowego, "Prace Naukowe AE w Katowicach. Analiza i prognozowanie zjawisk o charakterze niemetrycznym", pp. 59-69.

Zaborski A. (2014), Analiza preferencji sluchaczy uniwersytetu trzeciego wieku z wykorzystaniem wybranych metod niesymetrycznego skalowania wielowymiarowego, "Studia Ekonomiczne. Zeszyty Naukowe Uniwersytetu Ekonomicznego w Katowicach”, no. 195(14), pp. 216-224. 


\section{Wpływ wyboru triad na wyniki skalowania preferencji}

Streszczenie: $W$ metodzie triad dla zbioru n obiektów respondentom przedstawiane są wszystkie możliwe trójelementowe zestawy obiektów. Dla każdego zestawu respondent jest proszony o wskazanie, zgodnie ze swoimi preferencjami, pary obiektów najbardziej podobnych oraz pary obiektów najmniej podobnych. Mimo wielu zalet metoda triad nie jest często stosowana w praktyce. Liczba triad jest sześcienną funkcją liczby obiektów i rośnie bardzo szybko wraz ze wzrostem liczby obiektów. Celem pracy jest wskazanie możliwości skalowania preferencji w oparciu o zredukowaną liczbę triad. Zbadano także, czy zmiana zredukowanego zbioru triad wpływa na wyniki skalowania. Wyniki analizy zilustrowano empirycznym przykładem, w którym skalowanie preferencji dla różnych zbiorów triad przeprowadzono za pomocą programu TRISOSCAL.

Słowa kluczowe: pomiar preferencji, triady, skalowanie preferencji, TRISOSCAL

JEL: C38, C63, M31

\begin{tabular}{|l|l|}
\hline \multirow{2}{*}{ OPEN ACCESS } & $\begin{array}{l}\text { C by the author, licensee Łódź University - Łódź University Press, Łódź, Poland. } \\
\text { This article is an open access article distributed under the terms and conditions } \\
\text { of the Creative Commons Attribution license C(-BY } \\
\text { (http://creativecommons.org/licenses/by/3.0/) }\end{array}$ \\
\cline { 2 - 2 } & Received: 2016-12-28; verified: 2017-03-30. Accepted: 2017-07-31 \\
\hline
\end{tabular}

